\title{
Are marketing campaigns in Taiwan by foreign tobacco companies targeting young smokers?
}

\author{
C P Wen, T Chen, Y-Y Tsai, S P Tsai, W S I Chung, T Y Cheng, D T Levy, C C Hsu, R Peterson, \\ W-Y Liu
}

See end of article for authors' affiliations

Correspondence to: Chi Pang Wen, National Health Research Institutes, 35 Keyan Road, Zhunan Town, Miaoli County, Taiwan 350; cwengood@ nhri.org.tw

\begin{abstract}
Objective: To assess the impact of promotions on cigarette sales in Taiwan after the cigarette market opened to foreign companies, and to assess whether young smokers were targeted by these companies. Methods: Trends in cigarette sales, advertising expenditure, brand preference, and cigarette consumption were examined for the period following the 1987 opening of the cigarette market. Tobacco industry internal documents from Legacy Tobacco Documents Library of the University of California, San Francisco, were searched for corporate strategies on promoting youth consumption in Taiwan.

Results: Between 1995 and 2000, the inflation adjusted advertising expenditures by all foreign firms increased fourfold. Much of the expenditure was spent on brand stretching the Mild Seven (Japan) and Davidoff (Germany) brands in television advertising. By 2000, the market share of foreign cigarettes exceeded domestics by three to one among young smokers and the leading brand preferred by this segment shifted from the most popular domestic brand (Long Life) to a foreign brand (Mild Seven). Furthermore, there was a sudden increase of $16.4 \%$ in smoking rates among young adults (from $36.1 \%$ to 42.0\%) during the first five years after the market opened. This was also accompanied by increased per capita cigarette consumption and decreased age of smoking initiation. Industry documents confirmed the use of strategies targeted at the young. In particular, establishing new point of sale (POS) retail stores or promotional activities at POS were found to be more effective than advertising in magazines.

Conclusions: This study provides evidence that advertising increased with increased competition following the market opening, which, in turn, spurred cigarette sales and consumption. Foreign tobacco companies have deliberately targeted youth in Taiwan and succeeded in gaining three quarters of their cigarette purchases within a decade. Expanding youth consumption will incur excessive future health care costs borne by society. Foreign tobacco companies should be obligated to reimburse these expenses through higher tariffs on cigarettes.
\end{abstract}

$\mathrm{F}$ or nearly a century, the Monopoly Bureau (Taiwan Tobacco and Wine Monopoly Bureau) of the Taiwan government monopolised the distribution of cigarettes through state controlled licensed vending establishments. ${ }^{12}$ The monopoly was broken in 1987 and under the threat of trade sanctions under section 301 of the US Trade Act, ${ }^{3}$ US trade representatives successfully negotiated and started importing cigarettes. A contentious issue during negotiations was the extent of restrictions on promotional activities by tobacco companies.

In consideration of the serious public health concerns, ${ }^{3-5}$ Taiwan adopted promotional restrictions that resembled the US domestic model. The government banned direct tobacco advertising in all media except magazines, but allowed almost unlimited promotions via point of sale (POS) licensed tobacco selling outlets. These policies on tobacco promotion were largely carried forward into the Tobacco Hazard Control Act (THCA) of $1997 .{ }^{6}$ This Act, recognising the vulnerability of adolescents, reaffirmed restricting advertisements and promotions targeting adolescents.

The tobacco industry has long maintained that they do not market tobacco products to underage youth. ${ }^{78}$ They claim that the aim of their advertising is to persuade adults to maintain brand loyalty or to switch brands, rather than to increase the number of young or new smokers. ${ }^{9-11}$ However, the youth market is a major business growth area for tobacco companies, not only because youth are likely to experiment with cigarette smoking, but also because these young smokers grow into adult smokers, consuming the same products for decades. ${ }^{12}{ }^{13}$ A recent study concluded that tobacco companies were shown to have "an undeniable interest in marketing cigarettes to underage American smokers". ${ }^{7}$ The purpose of the current study is to assess whether an effort was made to market cigarettes to youth in Taiwan, and if so, to evaluate the impact of this marketing strategy on tobacco sales, brand preference, and smoking rates among this segment of the population. As Taiwan was one of several Asian countries forced to open its cigarette market in the late 1980s, Taiwan can serve as a valuable case study.

\section{METHODS}

Table 1 describes data sources used in this study, how they were collected, and the intended purpose for each particular dataset. Analyses were performed to compare the changes before and after market opening. To examine smoking rates, prevalence data for 2001 were obtained from Taiwan's National Health Interview Survey (NHIS). ${ }^{14}{ }^{15}$ Earlier data were obtained from a biennial survey by the Monopoly Bureau. ${ }^{16}$ The Monopoly Bureau conducted national surveys every other year since 1963, on tobacco consumption and behaviour. Import data beginning in 1986 were obtained from records in the Taiwan Customs Office and publications of the Monopoly Bureau. ${ }^{16}{ }^{17}$ Comparisons were made

Abbreviations: JTI, Japan Tobacco Inc; NHIS, National Health Interview Survey; POS, point of sale; PPS, probability proportional to size; THCA, Tobacco Hazard Control Act 
Table 1 Description of data sources

\begin{tabular}{|c|c|c|c|c|}
\hline Survey/source name & Purpose for citing the data & Year(s) used & How data were collected & Sample size \\
\hline $\begin{array}{l}\text { National Health Interview } \\
\text { Survey of Taiwan* }\end{array}$ & $\begin{array}{l}\text { Smoking prevalence, number of } \\
\text { young smokers, sources of cigarettes, } \\
\text { and age of smoking initiation }\end{array}$ & 2001 & $\begin{array}{l}\text { Face-to-face interview selected by multi-stage } \\
\text { stratified PPS sampling. For } 12-17 \text { year olds, } \\
\text { an additional written questionnaire collected }\end{array}$ & $\begin{array}{l}6592 \text { households, } \\
26685 \text { individuals }\end{array}$ \\
\hline $\begin{array}{l}\text { Biennial Survey Report and } \\
\text { Yearbook of the Monopoly } \\
\text { Bureau }\end{array}$ & $\begin{array}{l}\text { Smoking consumption rates, tobacco } \\
\text { sales, brand preference, and per } \\
\text { capita cigarette consumption }\end{array}$ & $\begin{array}{l}\text { 1963-1996 } \\
\text { (biennial) }\end{array}$ & $\begin{array}{l}\text { Self administered questionnaires for subjects } \\
\text { aged } 16 \text { or } 18 \text { years or older in the } \\
\text { households selected by the PPS sampling } \\
\text { method }\end{array}$ & $\begin{array}{l}3970-6000 \\
\text { households, } \\
13800-14500 \\
\text { individuals }\end{array}$ \\
\hline $\begin{array}{l}\text { Annual Statistics of the Directorate } \\
\text { General of Customs Office Taiwant }\end{array}$ & Cigarette import data by country & 1986-2000 & $\begin{array}{l}\text { Records on cigarette imports by country, } \\
\text { divided by sales, volume, and year }\end{array}$ & $\begin{array}{l}\text { All legally imported } \\
\text { cigarettes }\end{array}$ \\
\hline $\begin{array}{l}\text { Rainmaker Advertisement } \\
\text { Spending Report }\end{array}$ & $\begin{array}{l}\text { Tobacco brand advertisement } \\
\text { expenditures }\end{array}$ & 1995-2000 & $\begin{array}{l}\text { Real time recording of all advertisements } \\
\text { from } 69 \text { television channels ( } 4 \text { wireless, } 65 \\
\text { cable) } 67 \text { newspapers, } 91 \text { magazines, and } \\
8 \text { radio channels all year round }\end{array}$ & $\begin{array}{l}100 \% \text { of } \\
\text { advertisements } \\
\text { were collected }\end{array}$ \\
\hline $\begin{array}{l}\text { Eastern Integrated Consumer } \\
\text { Profile made by "Eastern } \\
\text { Online iSURVEY" }\end{array}$ & Cigarette advertisement readership & 1988-2001 & $\begin{array}{l}\text { Face-to-face interview for consumption } \\
\text { behaviour on consumer products for } \\
\text { subjects aged 13-64 selected by two } \\
\text { stage random PPS sampling }\end{array}$ & $\begin{array}{l}1200-1344 \\
\text { individuals }\end{array}$ \\
\hline $\begin{array}{l}\text { Legacy Tobacco Documents } \\
\text { Library at the University of } \\
\text { California, San Francisco } ¥\end{array}$ & $\begin{array}{l}\text { Assess whether tobacco companies } \\
\text { targeted youth in Taiwan }\end{array}$ & 1970-2000 & $\begin{array}{l}\text { With the use of the key word "Taiwan", } \\
\text { the website produced internal documents } \\
\text { from companies, mainly Philip Morris } \\
\text { and RJ Reynolds. }\end{array}$ & 2858 documents \\
\hline \multicolumn{5}{|c|}{$\begin{array}{l}\text { *http://www.nhri.org.tw/nhri_org/bs/biostat/e_proj5.htm } \\
\text { thttp://wwweng.dgoc.gov.tw/statisticsframe.htm } \\
\text { thttp://legacy.library.ucsf.edu/ } \\
\text { PPS, probability proportional to size. }\end{array}$} \\
\hline
\end{tabular}

between changes in cigarette sales volume and sale dollars for domestic and import cigarettes, particularly for the young smoker population, defined as 17 years old or younger.

Data on tobacco advertising and consumption were obtained from the commercial market research firms Rainmaker Industrial, Ltd, and Eastern Online, Ltd of Taipei, Taiwan. Rainmaker Industrial, Ltd provided data from 1995 to 2000. Advertising expenditures were inflation adjusted using a price index from Taiwan. Eastern Online, Ltd conducted interviews on samples of consumers across the country (Eastern Integrated Consumer Profile, or E-ICP survey) on magazine reading, smoking behaviour, and brand preferences for the years between 1988 and 2001.

We also examined industry documents regarding youth marketing. With the use of the key word "Taiwan" we searched the Legacy Tobacco Documents Library of University of California in San Franscisco ${ }^{18}$ and located 2885 documents, consisting mainly of documents from Philip Morris and RJ Reynolds. Each of these documents was reviewed by two individuals independently for wording or strategies related to young smokers in Taiwan. When such a document was found, it was then catalogued and placed into one of the four marketing categories: products, price, promotion, and place.

\section{RESULTS}

\section{Changes in tobacco sales, preferences, and smoking rates}

Table 2 shows tobacco consumption, tobacco sales, market shares and youth preferences. In 1986, foreign tobacco companies had $3 \%$ of the market share in sales dollars, which quickly jumped to $22 \%$ within a year after the market opened in 1987. Between 1995 and 2000, the market share of imports increased by $66 \%$ (from $33 \%$ to $55 \%$ of the entire market). Imported brands had less than half of the market share based on sales volume (quantity), but more than half based on sales dollars.

The country with the largest import share was the USA in 1987. This gradually shifted to Japan's favour in the late 1990s, with the foreign market share of the American tobacco firms dwindling from $72 \%$ to $10 \%$.

Preferences for imports by youth smokers jumped from $2 \%$ in 1986 to $77 \%$ in 2001 . This meant that virtually unknown foreign products became the favourites for three out of four young smokers within 15 years of the market opening. The proportion of youth favouring foreign tobacco (77\%) far exceeded that of the adults (48\%) based on sales volume. The leading brand preferred by youth shifted from the most popular domestic brand (Long Life) to foreign brands. Foreign brand preferences by this segment also shifted, with Marlboro (USA) being the leading foreign brand immediately after the market opening, constituting $50 \%$ of the foreign market share, but gradually being replaced by Mild Seven (Japan), constituting 70\% of the market share. ${ }^{19} 20$

With youth smoking being declared illegal, historical consumption data on underage youth smoking were unavailable in the statistics collected by the Monopoly Bureau. Instead, in this study, smoking prevalence rates for young adults (age 18-24) were examined over time. During the first five years after the opening of the market, there was a sudden growth of $16.4 \%$ in smoking prevalence (from $36.1 \%$ to $42.0 \%$ ). In the 1990s, smoking prevalence among young adults began declining, similar to the trend among older adults, reflecting increasing efforts by the government and others to implement tobacco control measures. In fact, the young adult smoking rate in 2001 would have been $6 \%$ lower, had the market not been opened..$^{21}$

Per capita consumption increased 15\% during this 14 year period, from 1604 cigarettes in 1986 to 1842 in 2002, with a sudden increase just following the market opening, followed by a steady but gradual increase afterwards. The median smoking initiation age in men also gradually fell, from slightly above age 20 in 1980 before the market opening to the age of 18 after the market opening. ${ }^{15}$

\section{Advertising expenditures in magazines and brand stretching on television}

Table 3 compares the changes in advertising expenditures for the leading brands from 1995 to 2000, years when government attention was directed toward restricting advertising. Advertising on non-cigarette merchandise employing the same brand name or logo as used with the corresponding cigarette brand has been termed "brand stretching." ${ }^{\text {"2 } 2}$ Within this five year period, the total expenditures for all forms of advertising by foreign tobacco companies, including that of brand stretching, increased nearly fivefold (451\%). During the same time period, the total sales value of imported cigarettes nearly 
Table 2 Changing trend of cigarette consumption, cigarette sales, market share, and youth preference for the imported brands

\begin{tabular}{|c|c|c|c|c|c|c|c|c|c|c|c|}
\hline \multirow[b]{2}{*}{ Year } & \multirow{2}{*}{$\begin{array}{l}\text { Per capita } \\
\text { consumption* } \\
\text { (pieces/year) }\end{array}$} & \multicolumn{2}{|c|}{ Sales† (US\$millions) } & \multicolumn{2}{|c|}{$\begin{array}{l}\text { Sales volumet in } 1000 \text { cases } \\
(1 \text { case }=500 \text { packs }=10000 \\
\text { pieces })\end{array}$} & \multicolumn{5}{|c|}{ Market share by foreign countriesł } & \multirow{2}{*}{$\begin{array}{l}\text { Import brand } \\
\text { preference amons } \\
\text { male youth } \\
\text { smokerst }\end{array}$} \\
\hline & & Domestics & Imports & Domestics & Imports & USA & UK & Germany & Japan & Others & \\
\hline 1986 & 1604 & $\$ 2139$ & $\$ 57(3 \%)$ & 3067 & $61(2 \%)$ & - & - & - & - & - & $2 \%$ \\
\hline 1987 & 1758 & $\$ 1975$ & $\$ 565(22 \%)$ & 2847 & $611(18 \%)$ & $13 \%$ & $3 \%$ & 0 & 0 & $2 \%$ & $19 \%$ \\
\hline 1990 & 1717 & $\$ 1849$ & $\$ 468(20 \%)$ & 2934 & $558(16 \%)$ & $12 \%$ & $4 \%$ & 0 & 0 & 0 & $30 \%$ \\
\hline 1995 & 1775 & $\$ 1452$ & $\$ 712(33 \%)$ & 2773 & $1020(27 \%)$ & $6 \%$ & $8 \%$ & $4 \%$ & $5 \%$ & $4 \%$ & $37 \%$ \\
\hline 2000 & 1842 & $\$ 1031$ & $\$ 1281(55 \%)$ & 2111 & 1967 (48\%) & $5 \%$ & $10 \%$ & $11 \%$ & $18 \%$ & $4 \%$ & $77 \%$ \\
\hline
\end{tabular}

*Source: Statistical yearbook of Taiwan 2000. Directorate-General of Budget, Accounting and Statistics, Taipei, 2001.

†Source: Taiwan tobacco \& wine statistical yearbook 1986-2000. Taiwan Tobacco and Wine Monopoly Bureau: Taipei, 1987-2001. Adjusted to the CPI (Consumer Price Index) of the year 2000. Average prices for domestic cigarettes were lower than that of imports, TWD20.7 v TWD28.9 in 1990 and TWD23.5 $v$ 37.7 in 2000 .

¥Source: Annual Statistics of Directorate General of Customs Office, Taiwan.

doubled, and imports generated revenues nearly 12 times the investment in advertisement expenditures.

With cigarette advertising restricted to magazines and POS by law, advertising expenditures on magazines increased by one third (35\%) between 1995 and 2000. Notably absent in 1995 were advertising for domestic brands. Even in 2000, domestic brands with nearly half the market share in Taiwan spent only $12 \%$ of total advertising expenditures. In 1995, foreign tobacco companies spent as much on brand merchandise advertising on TV as on magazines, but by year 2000, they spent nine times more for brand merchandise than on magazines.

Two brands, Japan Tobacco Inc's Mild Seven and the German Tobacco Company's Davidoff, contributed $90 \%$ of the entire expenditures in 2000 on cigarettes advertising in Taiwan, mainly in the form of brand stretched advertising. The number of TV appearances by Mild Seven Watch commercials in 2000 was 36813 , according to the Rainmaker Ad Spending Report. This amounted to showing the Mild Seven logos 4.2 times in any given hour on four wireless and 65 cable channels for the whole year, reaching young and old viewers alike. The market share of Mild Seven in Taiwan nearly doubled from $12.7 \%$ to $23.7 \%$ of the entire tobacco market. ${ }^{23}$ The market share of Davidoff also doubled from $6.8 \%$ to $14.7 \%$.

\section{Readership of magazines}

Readership data compiled from the Eastern-Integrated Consumer Profile survey was acquired by interviewing consumers. The data indicate that one third of adults did not read magazines at all, and, for those who did, the majority of magazines $(77 \%)$ that they read carried no cigarette advertisements. As a result, only one out of four adults read magazines with tobacco advertisements. Since adolescents are less likely to read magazines than adults, they would have read even less of the magazines with tobacco advertisements.

\section{Promotion at point of sale retail outlets}

Prior to 1987, tobacco was only available through a limited number of licensed establishments. ${ }^{13}$ Limited by the number and the business orientation of the licensed establishments, foreign tobacco companies, upon the market opening, sought new retail outlets and made use of tens of thousands of "unlicensed" POS locations, in violation of the 1986 agreements. With the addition of businesses selling imported cigarettes, roadside stalls selling betel quid substantially boosted their fledgling betel quid business. ${ }^{24}$ At the same time, another important venue of retail outlets had become available with the advent of the rapid growth of franchised convenience stores in late 1980s and the early 1990s. Having one token license, thousands of convenience stores such as "7-Eleven", characteristically open 24 hours a day, became major cigarette vending outlets. In these franchised stores, tobacco companies have outbid other products to acquire premium display shelf space. For example, Philip Morris secured a contract to display "in front of/next to the cashier machine at 380 7-Eleven stores in 1989, which were expanding at 15 new stores per month",25

Table 3 Comparison of advertising expenditures* between 1995 and 2000 by the manufacturers of leading brands for cigarettes and for brand merchandise

\begin{tabular}{|c|c|c|c|c|c|c|c|c|c|c|c|}
\hline \multirow[b]{3}{*}{ Brands } & \multirow{2}{*}{\multicolumn{2}{|c|}{$\begin{array}{l}\text { Cigarette } \\
\text { advertisement† }\end{array}$}} & \multicolumn{6}{|c|}{ Brand merchandise advertisement } & \multirow{2}{*}{\multicolumn{2}{|c|}{$\begin{array}{l}\text { Total } \\
\text { advertisements }\end{array}$}} & \multirow{3}{*}{$\begin{array}{l}\text { Percentage increases } \\
\text { between } 1995 \text { and } 2000\end{array}$} \\
\hline & & & \multicolumn{2}{|c|}{ Magazine } & \multicolumn{2}{|c|}{ Newspaper } & \multicolumn{2}{|c|}{ Television } & & & \\
\hline & $1995^{*}$ & 2000 & $1995^{*}$ & 2000 & $1995^{*}$ & 2000 & $1995^{*}$ & 2000 & $1995^{*}$ & 2000 & \\
\hline \multicolumn{12}{|l|}{ Imported } \\
\hline Mild Seven & $\$ 0.57$ & $\$ 0.66$ & $\$ 0.97$ & $\$ 0.99$ & $\$ 0.32$ & $\$ 0.07$ & $\$ 2.39$ & $\$ 29.98$ & $\$ 4.25$ & $\$ 31.70$ & $644 \%$ \\
\hline 555 & $\$ 1.31$ & $\$ 0.59$ & $\$ 0.01$ & $\$ 0.10$ & $\$ 0.24$ & $\$ 0.07$ & $\$ 0.10$ & $\$ 0.00$ & $\$ 1.65$ & $\$ 0.76$ & - \\
\hline Marlboro & $\$ 0.76$ & $\$ 0.62$ & $\$ 0.32$ & $\$ 0.11$ & $\$ 0.34$ & $\$ 0.00$ & $\$ 0.32$ & $\$ 0.00$ & $\$ 1.74$ & $\$ 0.73$ & - \\
\hline Parliament & $\$ 0.48$ & $\$ 0.00$ & $\$ 0.14$ & $\$ 0.00$ & $\$ 0.03$ & $\$ 0.00$ & $\$ 0.00$ & $\$ 0.00$ & $\$ 0.65$ & $\$ 0.00$ & - \\
\hline Davidoff & $\$ 0.48$ & $\$ 0.50$ & $\$ 0.01$ & $\$ 0.15$ & $\$ 0.00$ & $\$ 0.01$ & $\$ 0.00$ & $\$ 21.20$ & $\$ 0.48$ & $\$ 21.86$ & $4429 \%$ \\
\hline Others & $\$ 1.71$ & $\$ 3.56$ & $\$ 0.11$ & $\$ 0.00$ & $\$ 0.00$ & $\$ 0.00$ & $\$ 0.00$ & $\$ 0.01$ & $\$ 1.82$ & $\$ 3.57$ & $96 \%$ \\
\hline Subtotal & $\$ 5.32$ & $\$ 5.93$ & $\$ 1.55$ & $\$ 1.35$ & $\$ 0.94$ & $\$ 0.15$ & $\$ 2.80$ & $\$ 51.19$ & $\$ 10.61$ & $\$ 58.62$ & $451 \%$ \\
\hline Domestic & $\$ 0.00$ & $\$ 0.81$ & $\$ 0.00$ & $\$ 0.00$ & $\$ 0.00$ & $\$ 0.00$ & $\$ 0.00$ & $\$ 0.00$ & $\$ 0.00$ & $\$ 0.81$ & - \\
\hline Total & $\$ 5.32$ & $\$ 6.73$ & $\$ 1.55$ & $\$ 1.35$ & $\$ 0.94$ & $\$ 0.15$ & $\$ 2.80$ & $\$ 51.19$ & $\$ 10.61$ & $\$ 59.43$ & $458 \%$ \\
\hline
\end{tabular}

*Expenditure expressed in US\$million and adjusted to the CPI (Consumer Price Index) in the year 2000.

†Cigarette advertisement was legally restricted to magazines only.

†Calculated as (total advertisements in 2000 - total advertisements in 1995)/total advertisements in 1995.

Source: Complied from Rainmaker Industrial, Ltd, Taipei, Taiwan. 
Table 4 Sources of cigarette acquisition by under age smokers in Taiwan

\begin{tabular}{llllll}
\hline & Friends & $\begin{array}{l}\text { Members of } \\
\text { family }\end{array}$ & $\begin{array}{l}\text { Betel nut } \\
\text { stands }\end{array}$ & $\begin{array}{l}\text { Convenience } \\
\text { stores }\end{array}$ & $\begin{array}{l}\text { Total number } \\
\text { surveyed }\end{array}$ \\
\hline $\begin{array}{l}\text { Occasional smokers } \\
\text { Daily smokers }\end{array}$ & $33 \%(49)$ & $11 \%(16)$ & $17 \%(25)$ & $39 \%(57)$ & 147 \\
All smokers & $12 \%(5)$ & $5 \%(2)$ & $28 \%(12)$ & $56 \%(24)$ & 43 \\
\hline Source: Age 17 or under who indicated having ever smoked in written questionnaire response conducted during \\
the National Health Interview Survey 2001. Number in parenthesis is the number of underage smokers.
\end{tabular}

and to build "the overhead rack and display unit at the check out cashier area" at 30 Circle K stores in Taiwan. By 2001, the NHIS nationwide survey showed that nearly half of underage smokers acquired their cigarettes from the convenience stores and an additional fifth (19\%) from betel quid stands (table 4).

The importance of these POS retail outlets was well recognised and pursued by tobacco companies in Taiwan. A survey report by RJ Reynolds concluded that the impact of POS promotion was much greater than magazines in terms of advertising awareness and brand registration. ${ }^{26}$ In contrast, they became aware of the limited reach and readership of magazines, by noting "on average, 7 out of 10 smokers could not understand or state the message in magazine ads, and thus (it is) not a strong medium". ${ }^{26}$

\section{Targeting young smokers}

Table 5 lists statements and comments from industry documents, providing further evidence of attempts to target the young. The corporate plan of Philip Morris Taiwan repeatedly emphasised the need to place business priority on young and new smokers. ${ }^{27}$ By noting that new smokers were mostly smoking imported brands, the company manager in Taiwan concluded, "Starters... are a very important source of (our) import development". Targeting starters (new smokers) would be tantamount to targeting youth, as two thirds of new smokers were underage youth in Taiwan. ${ }^{14}$

Tobacco companies repeatedly recruited young smokers for focus groups, most notably those aged $18-24$ years, ${ }^{28}$ to determine the characteristics that had initially attracted them to smoking and to identify the nature of the ideal cigarettes in their views. ${ }^{28-30}$ Surveys also provided data on whether the brand appeals were more product related or image related; they discussed how emphasising mild/low/lights ${ }^{31-33}$ would attract young smokers in Taiwan, ${ }^{34}{ }^{35}$ and the price reactions of young smokers. ${ }^{36}$ The cartoon figure Joe $\mathrm{Camel}^{37}$ was transported to Taiwan. The "Camel Smooth Character"

Table 5 Industry documents containing statements on marketing tobacco products to youth

\begin{tabular}{|c|c|c|c|}
\hline Category & Ref number - document title & Statement/comment & Company involved \\
\hline \multirow[t]{4}{*}{ Product } & $\begin{array}{l}28 \text { - A Qualitative Study on } \\
\text { Switching/Low Tar }\end{array}$ & $\begin{array}{l}\text { "Identified the appeal to young smokers is more } \\
\text { product related than image related" }\end{array}$ & $\begin{array}{l}\text { Presented to Philip Morris by Survey } \\
\text { Research Taiwan, September } 1993\end{array}$ \\
\hline & $\begin{array}{l}31 \text { - Parliament Performance } \\
\text { Analysis Taiwan }\end{array}$ & $\begin{array}{l}\text { "Our Ad Objective: To project a mild and relaxing image"; } \\
\text { Mild Seven found appealing to students and } 20-30 \text { year olds }\end{array}$ & $\begin{array}{l}\text { Survey results for Philip Morris Asia, } \\
\text { January } 1994\end{array}$ \\
\hline & $\begin{array}{l}32 \text { - Special Analysis-A New } \\
\text { Virginia Brand for Taiwan }\end{array}$ & $\begin{array}{l}\text { "Long Life Mild has replaced Long Life Regular as the most } \\
\text { popular brand among starters" }\end{array}$ & $\begin{array}{l}\text { Survey results for Philip Morris, } \\
\text { August } 1991\end{array}$ \\
\hline & $\begin{array}{l}33 \text { - Marlboro New Concept } \\
\text { Test - Taipei }\end{array}$ & $\begin{array}{l}\text { "Packing } 14 \text { 's (instead of } 20 \text { 's) has the potential to attract } \\
\text { young smokers" }\end{array}$ & $\begin{array}{l}\text { Survey results on male aged 18-29 } \\
\text { presented to Philip Morris, June } 1993\end{array}$ \\
\hline Price & $\begin{array}{l}36 \text { - Taipei Cigarette BPTO } \\
\text { (Brand Price Trade Off) Study }\end{array}$ & $\begin{array}{l}\text { How a price increase will affect smokers' brand switching } \\
\text { behavior, particularly among the young }\end{array}$ & $\begin{array}{l}\text { Report by Research Intl Asia to Philip } \\
\text { Morris Taiwan December } 1993\end{array}$ \\
\hline \multirow[t]{7}{*}{ Promotion } & $\begin{array}{l}27 \text { - Philip Morris Asia Region } \\
\text { Overview - Taiwan }\end{array}$ & $\begin{array}{l}\text { "Starters (in Taiwan) are a very important source of our } \\
\text { import development" }\end{array}$ & Corporate plan for Philip Morris Taiwan \\
\hline & 29 - Marlboro Focus Group & "A light cigarette is perceived to be young and elegant" & $\begin{array}{l}\text { Survey results to Philip Morris by Survey } \\
\text { Research Taiwan, March } 1993\end{array}$ \\
\hline & $\begin{array}{l}30 \text { - Marketing Research Report } \\
\text { (... Main Findings from Focus Group } \\
\text { on Marlboro Ad Test) }\end{array}$ & $\begin{array}{l}\text { "The main reason for smoking imported brands (by young } \\
\text { smokers) is because its taste is generally lighter than local } \\
\text { cigarettes" }\end{array}$ & $\begin{array}{l}\text { Survey results presented to Philip Morris, } \\
\text { August } 1993\end{array}$ \\
\hline & 34 - Parliament Ad Test (FDG) & $\begin{array}{l}\text { "To young smokers, we should convey both light/mild, and } \\
\text { a relaxing feeling (in our ads)" }\end{array}$ & $\begin{array}{l}\text { Focus group results presented to Philip } \\
\text { Morris Asia by Survey Research Taiwan, } \\
\text { February } 1993\end{array}$ \\
\hline & $\begin{array}{l}35 \text { - Taiwan Cigarette Market } \\
\text { Opportunity Study }\end{array}$ & $\begin{array}{l}\text { "The young segment (students under 25)... is the most } \\
\text { important segment to pursue" }\end{array}$ & $\begin{array}{l}\text { In home interviews in Taiwan for Philip } \\
\text { Morris Asia by Michael Normile } \\
\text { Marketing, Inc May } 1989\end{array}$ \\
\hline & $\begin{array}{l}39 \text { - Virginia Slims Below-the-Line } \\
\text { Programs }\end{array}$ & $\begin{array}{l}\text { Offering cigarettes for sampling in beauty salons and top } \\
\text { discos and Swatch watch promotions in convenience stores }\end{array}$ & $\begin{array}{l}\text { Philip Morris Asia program update, } \\
\text { August } 1990\end{array}$ \\
\hline & $\begin{array}{l}38 \text { - Camel Smooth Character } \\
\text { Campaign/Taiwan to promote } \\
\text { the fun of Camel Mild cigarettes }\end{array}$ & $\begin{array}{l}\text { "I suggest strengthening the answer to reflect first and } \\
\text { foremost that we are not giving t-shirts away to minors" } \\
\text { in the "Camel Smooth Character" Campaign }\end{array}$ & RJ Reynolds 1993 \\
\hline \multirow[t]{2}{*}{ Placement } & $\begin{array}{l}25-\text { Key Account Program for } \\
\text { convenience Stores }\end{array}$ & $\begin{array}{l}\text { "We have a contract to display our product in front of/next } \\
\text { to the cashier machine in all 7-Eleven stores" }\end{array}$ & Philip Morris 1989 \\
\hline & $\begin{array}{l}26 \text { - Telephone survey on media } \\
\text { effectiveness }\end{array}$ & $\begin{array}{l}\text { "POS advertising made a greater impact than magazines } \\
\text { in terms of advertising awareness and brand registration } \\
\text { (among young smokers)" }\end{array}$ & $\begin{array}{l}\text { Report presented to RJ Reynolds by } \\
\text { Marketing Research } 1988\end{array}$ \\
\hline
\end{tabular}


campaign was launched to promote "the fun and awareness of Camel Mild Box" cigarettes using the "Joe" character. ${ }^{9}$ RJ Reynolds had planned to give away "Joe" T-shirts to minors in Taiwan, only to rescind and to emphasise the opposite when challenged by the John Tung Foundation, an antismoking non-governmental organisation. ${ }^{38}$

The documents revealed a number of other promotional strategies directed at young smokers. They included: (1) the pursuit of youth oriented activities such as "fashion night promotions" to promote Virginia Slim, exchanging empty packs for raffle or disco tickets, and Swatch watch redemptions $^{39} ;(2)$ the aggressive promotion of "light and mildness" for new smokers, ${ }^{28}$ and implying a safer product with less health hazards ${ }^{28}{ }^{40} ;$ (3) the association of imports as environmentally sound, with messages in Mild Seven advertising highlighting serene and clean environments; (4) the presentation of a higher class product with better packaging and higher pricing than the local products, consistent with young people's yearning for maturity, independence, and success 35364142 ; and (5) making the product widely available and easily accessible to young people at POS outlets located at most street corners. ${ }^{36} 4344$

\section{DISCUSSION}

Similar to the conclusion of a recent US study, ${ }^{7}$ we found that foreign tobacco companies in Taiwan had "an undeniable interest in marketing cigarettes to underage smokers". They transplanted aggressive marketing strategies to Taiwan and covertly targeted youth. Of more concern to tobacco control in Taiwan, however, is that these strategies succeeded in greatly expanding the market share of foreign firms and generally increasing cigarette consumption. Smoking has long been illegal for underage youth in Taiwan, and yet nearly one out of four $(23 \%) 17$ years old boys admits to being a current smoker.

Industry practices in Taiwan contradict industry claims that they focus marketing strategies on gaining market share from existing smokers and not attracting new (young) smokers. ${ }^{38}{ }^{45}$ The importance of the small underage youth market is that this segment contributes two thirds of all new smokers. ${ }^{14}$ Recognising the fact that "the brands which these beginning smokers accept and use will become the dominant brands in future years", ${ }^{\prime}$ foreign companies conscientiously placed their business priorities disproportionately on this relatively small but important market of young and new smokers. ${ }^{38}$

As noted by a tobacco trade journal, "foreign tobacco companies have essentially introduced the full spectrum of cigarette advertising to Taiwan". ${ }^{46}$ Following attempts to limit advertising, expenditures on cigarette advertisements, previously minimal and unnecessary, increased nearly fivefold between 1995 and 2000, while the return on their advertising investment was 12 -fold. Two brands, Mild Seven and Davidoff, made huge gains in sales and doubled their market share by resorting to massive TV advertising through brand stretching, ostensibly selling watches and coffee, respectively. They spent eight times more on brand stretching advertisements than on legal magazine advertisements. Circumventing the bans on cigarette advertising, the magnitude of these activities caught Taiwan off guard. The Mild Seven brand has since become, by far, the leading brand among young smokers in Taiwan.

In the decade after the market opened, three out of four young smokers developed a preference for foreign brands, in contrast to less than one in 20 before the market opened. This growth outpaced the increased preference for foreign brands displayed by adults, indicating that young and new smokers were more responsive and more vulnerable to promotional messages. ${ }^{11} 4748$ Increased consumption and a younger age of

\section{What this paper adds}

Tobacco companies maintain they never target underage youth or non-smokers. Tobacco company documents show foreign tobacco companies targeted young smokers in Taiwan. Foreign tobacco companies increased their advertising expenditure, skirted the law via brand stretching, and engaged in aggressive promotional activities at point of sale retail outlets, catering to young and old smokers. Advertising increased consumption of imported cigarettes by the young.

smoking initiation appeared to have resulted from television advertising in promoting brand recognition and experimental trial among young smokers. By creating a competitive marketplace, the market opening led to increased consumption, despite increased tobacco control activities.

Relatively few studies have examined the industry's attempt to reach youth at the POS. ${ }^{22} 434950$ Tobacco companies are known for their strengths in POS advertising. ${ }^{51}{ }^{52}$ It appears that much of the success of tobacco industry in reaching youth in Taiwan could be credited to their success in POS investment. The combined effect of tens of thousands of betel quid stalls and convenience stores added to sell cigarettes after the market was opened, creating barrier-free access, and the aggressive promotional programs launched inside the convenience stores, along with displaying cigarettes on the most visible shelves next to the cash register, contributed to the success of the POS methodology. ${ }^{25}$ In addition, this investment resulted in the unexpected proliferation of smuggled cigarettes, ${ }^{53}$ which were highly valued by young smokers. ${ }^{54}$

Industry documents also reveal a host of other strategies suggestive of targeting youth, not unlike those uncovered for the USA by Cummings et al. ${ }^{7}$ They included "fashion night promotions", ${ }^{39}$ promoting "light and mildness", ${ }^{28}$ the Camel Smooth Character Campaign, ${ }^{38}$ and, most notably, the repeated recruitment of 18-24 years old smokers for focus groups. ${ }^{29}$ Essentially, tobacco companies transplanted the successful strategies that they developed earlier for the USA to Taiwan. While these companies have paid a hefty price in the USA through the Master Settlement Agreement, ${ }^{55}$ the prospect for Taiwan to reach a similar agreement is small. Nevertheless, nearly half of the new youth who smoke in Taiwan will develop smoking related diseases. ${ }^{56}$ These smokers will incur excess medical expenditures which society will bear under the National Health Insurance Program. At a minimum, these foreign tobacco companies should be held responsible, and be required to reimburse the higher health expenditures through increased tariffs levied on their products. By way of higher taxes, not only will social justice be served, but also youth smoking rates would decline, a winwin outcome. Those companies who are unwilling to share the future social cost should be asked to leave Taiwan's market.

This study has several limitations. First, the availability of industry documents was limited to American tobacco companies. Japan Tobacco Inc (JTI) has become the leading company for imported cigarettes, and the lack of internal papers from this company hampered our first hand knowledge of the strategies employed toward youth. Nevertheless, documents from Philip Morris and RJ Reynolds revealed the marketing methods that JTI used to capture the lion's share of the foreign market in Taiwan. ${ }^{53}$ In addition, the JTI purchase of RJ Reynolds International in 1999 expanded its market share and made the role of JTI all the more important. Efforts to obtain additional internal documents, not only from JTI but also from Taiwan's Monopoly Bureau, 
are critically important to tobacco control efforts in Taiwan. These documents could very likely yield further insights to industry's secret in expanding the youth market. Second, the earlier smoking data on underage youth, particularly on preferences for Japanese or domestic brands, were incomplete and compiled from limited survey data from competitors. Brand specific data should be included in the future surveys, since the historical trend is an important indicator for evaluating tobacco control. Third, the sales and volume data on tobacco used in this study came from official records. Smuggling, which varied from year to year, were not included, but played an important role, amounting to over $20 \%$ of the legal products in some years in Taiwan. ${ }^{54}$

In conclusion, Taiwan serves as a compelling case that advertising increases with competition and that competition spurs growth in total cigarette sales. Through aggressive marketing strategies and conscious efforts targeting the youth, foreign tobacco companies gained more than half of the overall market share and more than three quarters of the youth market. Expanding consumption among young smokers will incur excesses in future health care expenditures, which should be reimbursed through levying higher tariffs on products from foreign tobacco companies.

\section{Authors' affiliations}

C P Wen, T Y Cheng, W S I Chung, C C Hsu, R Peterson, Health Policy Division, National Health Research Institutes, Taipei, Taiwan

T Chen, Tulane University School of Tropical Medicine and Public Health, New Orleans, Louisiana, USA

Y-Y Tsai, Department of Communication Studies, Tzu-Chi University, Hualein, Taiwan

W-Y Liu, Department of Speech Communication, Shih Hsin University, Taipei, Taiwan

S P Tsai, The University of Texas School of Public Health, Houston, Texas, USA

D T Levy, The University of Baltimore, Pacific Institute for Research and Evaluation, Maryland, Baltimore, USA

Competing interests: none declared

\section{REFERENCES}

1 Taiwan Tobacco and Wine Monopoly Bureau. Taiwan Tobacco and Wine Monopoly Bureau statistical yearbook. 2001: part 1. Summary analysis. Taipei, Taiwan: Taiwan Tobacco and Wine Monopoly Bureau, 2002.

2 Huang SC. Epidemiological studies on smoking. Taipei, Taiwan: Health Promotion and Disease Prevention Committee, Forum, National Health Research Institutes, Taiwan, 2000.

3 US Department of Health and Human Services. Section 301 of the Trade Act of 1974. Reducing tobacco use: a report of the Surgeon General. Atlanta: Office on Smoking and Health, 2000:312-15.

4 Connolly G. American Cancer Society. Testimony of Gregory N. Connolly, D.M.D., M.P.H. On Behalf of the American Cancer Society before the U.S. Trade Representative on Section 301 Thailand 890919. September 19, 1989. Philip Morris. Bates No: 2500077449/7461, http://legacy.library.ucsf.edu/ $\mathrm{tid} / \mathrm{vkj} 19 \mathrm{e} 00$ (Accessed August 27, 2003)

5 Chen T. Historical review of market penetration and use of tobacco in Northern East Asia, and 10th anniversary review of APACT's contribution to the battle against tobacco in the Asia Pacific region. APACT Tenth Anniversary Symposium Proceedings 1989:11-16.

6 Bureau of Health Promotion. The Tobacco Hazards Control Act. Compendium of Tobacco Control Related Acts in Taiwan. Taipei, Taiwan: Bureau of Health Promotion, Department of Health, Taiwan, 2001.

7 Cummings KM, Morley CP, Horan JK, et al. Marketing to America's youth: evidence from corporate documents. Tobacco Control 2002; 11 (suppl I):i5-17.

8 Perry $\mathrm{CL}$. The tobacco industry and underage youth smoking: tobacco industry documents from the Minnesota litigation. Arch Pediatr Adolesc Med 1990;153:935-41.

9 RJR Taiwan Branch. [Faxed Memo from Christine Chui RJR to Joseph Pei MDK] June 4,1993. Bates No. 51522871 1/8716. RJ Reynolds. Available at: http://legacy.library.ucsf.edu/tid/vlb03d00 (Accessed August 27, 2003)

10 Leiss W, Kline S, Jhally S. Social communication in advertising. Scarborough, Ontario: Nelson Canada, 1990.

11 Jacobson PD, Lantz PM, Warner KE, et al. Combating teen smoking: research and policy strategies. Michigan: The University of Michigan Press, 2001.

12 Evans N, Farkas A, Gilpin E, et al. Influence of tobacco marketing and exposure to smokers on adolescent susceptibility to smoking. J Natl Cancer Inst 1998;7:1538-45.
13 King C III, Siegel M, Celebucki $C$, et al. Adolescent exposure to cigarette advertising in magazines: an evaluation of brand-specific advertising in relation to youth readership. JAMA 1998;279:516-20.

14 National Health Research Institutes. National Health Interview Survey 2001 in Taiwan. http://www.bhp.doh.gov.tw/people/people-index.htm.

15 Cheng TY, Wen CP, Tsai MC, et al. The current status of smoking behavior in Taiwan: Data analysis from National Health Interview Survey in 2001 (in Chinese). Taiwan J Public Health 2003;22:453-64.

16 Taiwan Tobacco and Wine Monopoly Bureau. Report on tobacco and wine consumption survey 1963-1996. Taipei, Taiwan: Taiwan Tobacco and Wine Monopoly Bureau, 1964-1997.

17 Directorate General of Customs Office. Annual statistics, Taipei, Taiwan 1986-2000.

18 Glantz S, Slade J, Bero L. The cigarette papers, University of California Press.http://legacy.library.ucsf.edu/index.html (Accessed August 27, 2003)

19 Lok H. Fax to James Ho [Taipei Cigarette Market Study 1987] August 24, 1987. Bates No. 2504048238/8253. Phillip Morris. http:// legacy.library.ucsf.edu/tid/dtx32e00 (Accessed Auguest 27, 2003).

20 Philip Morris Asia Inc. [General Consumer Tracking Study: Taiwan 1994] July 1994. Bates No. 2504020315/0361. http://legacy.library.ucsf.edu/tid/ osz32e00 (Accessed Auguest 27, 2003).

21 Hsu CC, Levy DT, Wen CP, et al. The effect of market opening on trends in smoking rates in Taiwan. Health Policy (in press).

22 MacFadyen L, Hastings G, MacKintosh AM. Cross sectional study of young people's awareness of and involvement with tobacco marketing. $B M$ $2001 ; 332: 513-7$

23 Personal communication, from Director Ching Li Lin of John Tung Foundation 2002.

24 Wen CP, Cheng TY, Eriksen MP. How opening the cigarette market led to an increase in betel quid use in Taiwan. Public Health (in press).

25 Kwong D. PMAl Taiwan. Key Account Program for Convenience Store. October 24, 1989. Bates No. 2504009909/9910. Philip Morris. http:// legacy.library.ucsf.edu/tid/emq19e00 (Accessed August 27, 2003).

26 RJR Intl. Telephone survey on media effectiveness. In: 1988 (880000) Consumer research summaries. Annual Report. 1988. Bates No. 516411814 (In: 516411608/1846), RJR. Reynolds. http://legacy.library.ucsf.edu/tid/ ujy82d00 (Accessed August 21, 2003).

27 PMI Marketing Services. Philip Morris Asia Region Overview. March, 1990. Bates No. 2501081755/1849. Philip Morris. http://legacy.library.ucsf.edu/ $\mathrm{tid} /$ zac29e00 (Accessed August 27, 2003).

28 Survey Research Taiwan. A Qualitative Study on Switching Low Tar Study. September 29, 1993. Bates No. 2504020559/0582. Philip Morris. http:// legacy.library.ucsf.edu/tid/ufr19e00 (Accessed August 27, 2003).

29 Survey Research Taiwan. Marlboro Focus Group. No. 1 of 3 copies for Philip Morris Asia Inc. March 1993. Bates No. 2504021578/1625. http:// legacy.library.ucsf.edu/tid/ter19e00 (Accessed August 27, 2003).

30 Philip Morris. Marketing Research Proposal. August 19, 1993. Bates No. 2504021470/1476. http://legacy.library.ucsf.edu/tid/wer19e00 (Accessed August 27, 2003).

31 Philip Morris Asia Inc. Parliament Performance Analysis Taiwan. January 1994. Bates No. 2504021082/1098. Philip Morris. http:// legacy.library.ucsf.edu/tid/Ifr19e00 (Accessed August 27, 2003)

32 Philip Morris. Special analysis - a new Virginia brand - Taiwan. August 1991 Bates No. 2504027887/7907. http://legacy.library.ucsf.edu/tid/deul9e00 (Accessed August 27, 2003).

33 Philip Morris. Marlboro new concept test - Taipei. June 1993. Bates No. 2504021480/1534. http://legacy.library.ucsf.edu/tid/yer19e00 (Accessed August 27, 2003)

34 Survey Research Taiwan. Parliament ad test (FGD). February 1993. Bates No. 2504021537/1575. Philip Morris. http://legacy.library.ucsf.edu/tid/ rer19e00 (Accessed August 27, 2003).

35 Michael Normile Marketing. Taiwan cigarette market opportunity study. May 1989. Bates No. 2504027959/8084. Philip Morris. http:// legacy.library.ucsf.edu/tid/vdul9e00 (Accessed August 27, 2003).

36 Research Intl Asia Pte. Ltd. Taipei cigarette BPTO 1993: A quantitative investigation of price sensitivities among smokers in Taipei using brand price trade off, December 1993. Bates No. 2504020011/0108. Philip Morris. http://legacy.library.ucsf.edu/tid/dfq19e00 (Accessed August 27, 2003)

37 Difranza J, Richards J, Paulman P, et al. RJR Nabisco's cartoon camel promotes camel cigarettes to children. JAMA 1991;266:3149-53.

38 RJ Reynolds Tobacco International. [Memo from Don Albert to Brenda Follmer] May 19, 1993. Bates No. 515228723/8723. RJ Reynolds. http:// legacy.library.ucsf.edu/tid/amb03d00 (Accessed August 27, 2003).

39 Philip Morris. Virginia Slims below-the-line programs update Hong Kong Taiwan Japan Korea. August, 1990. Bates No. 2500152276/2329. http:// legacy.library.ucsf.edu/tid/sfn 19 e00 (Accessed August 27, 2003).

40 Kozlowski L, Goldberg M, Yost B, et al. Smokers' misperceptions of light and ultra-light cigarettes may keep them smoking. Am J Prev Med 1998;15:9-16.

41 US Department of Health and Human Services. Marketing cigarettes to women. Women and smoking: a report of the Surgeon General. Atlanta, Georgia: US Department of Health and Human Services, Centers for Disease Control and Prevention, National Center for Chronic Disease Prevention and Health Promotion, Office on Smoking and Health, 2001:490-546.

42 US Department of Health and Human Services. Advertising and promotion. Reducing tobacco use: a report of the Surgeon General. Atlanta, Georgia: US Department of Health and Human Services, Centers for Disease Control and Prevention, National Center for Chronic Disease Prevention and Health Promotion, Office on Smoking and Health, 2000:161-77.

43 Donovan R, Jancey J, Jones S. Tobacco point of sale advertising increases positive brand user imagery. Tobacco Control 2002;11:191-4. 
44 Lal A, Scollo M. Big Mac index of cigarette affordability. Tobacco Control 2002;11:280-2.

45 Difranza JR, Eddy JJ, Brown LF, et al. Tobacco acquisition and cigarette brand selection among youth. Tobacco Control 1994:3:334-8.

46 Schudson M. Cigarette advertising and 'targeting'. July 28, 1992. Bates No. 2503017371/7391. Philip Morris. http://legacy.library.ucsf.edu/tid/ cpz32e00 (Accessed August 27, 2003).

47 Pierce JP, Gilpin E, Burns DM, et al. Does tobacco advertising target young people to start smoking? Evidence from California. JAMA 1991;266:3154-8.

48 Wayne GY, Connolly GN. How cigarette design can affect with initiation into smoking: Camel Cigarette 1983-93. Tobacco Control 2002; 11 (suppl I):i32-9.

49 Choi WS, Ahluwalia JS, Harris KJ, et al. Progression to established smoking: the influence of tobacco marketing. Am J Prev Med 2002;22:228-33.
50 Peters J, Betson CL, Hedley AJ, et al. Recognition of cigarette brand names and logos by young children in Hong Kong. Tobacco Control 1995;4:150-5.

51 Thompson S. And the winner for merchandising achievement is ... Brandweek 1999:40:50.

52 Henriksen L, Feighery EC, Schleicher NC, et al. Reaching youth at the point of sale: cigarette marketing is more prevalent in stores where adolescents shop frequently. Tobacco Control 2004;13:315-8.

53 Wen CP, Cheng TY, Eriksen MP, et al. The impact of cigarette market opening in Taiwan. Tobacco Control 2005;14(suppl I):i4-9.

54 Tsai YW, Sung HY, Yang CL, et al. The behaviour of purchasing smuggled cigarettes in Taiwan. Tobacco Control 2004;12:28-33.

55 King C III, Biegel M. The Master Settlement Agreement with tobacco industry and cigarette advertising in magazines. N Engl J Med 2001:345:504-11.

56 Wen CP, Tsai SP, Chen CJ, et al. The mortality risks of smokers in Taiwan part I: cause-specific mortality. Prev Med 2004;39:528-35.

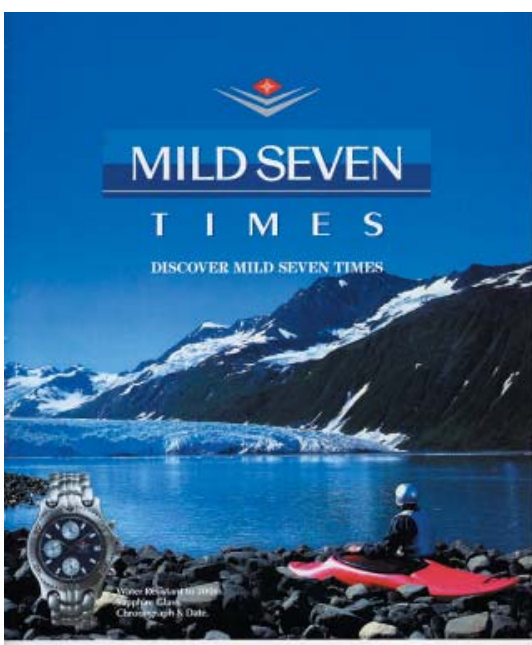

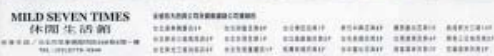

Brand stretching advertisement selling watches, carrying the same logo and the same theme as Mild Seven cigarettes

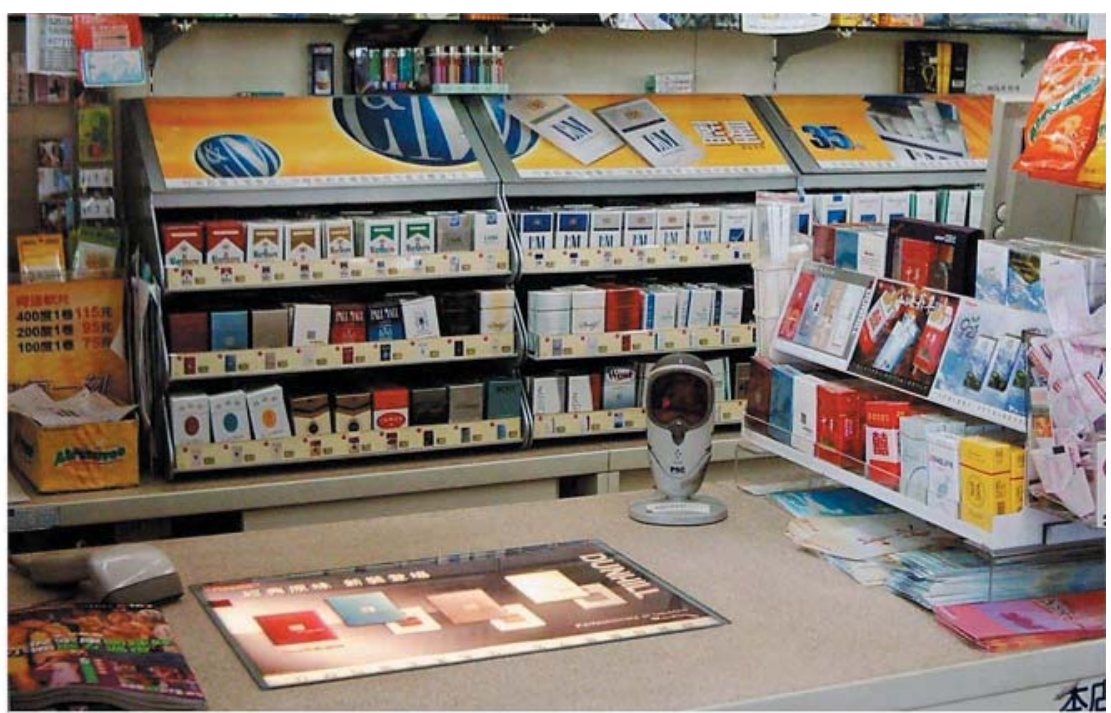

Convenience store checkout counter, dominated by cigarettes 